Article

\title{
Impact of Agricultural Land Loss on Rural Livelihoods in Peri-Urban Areas: Empirical Evidence from Sebougou, Mali
}

\author{
Brahima Coulibaly ${ }^{1}$ and Shixiang $\mathrm{Li}^{1,2, *(\mathbb{D})}$ \\ 1 School of Public Administration, China University of Geosciences, Lumo Road 388, Wuhan 430074, China; \\ brecoulibaly@cug.edu.cn \\ 2 School of Public Administration, Mineral Resources Strategy and Policy Research Center, \\ China University of Geosciences, Lumo Road 388, Wuhan 430074, China \\ * Correspondence: lishixiang@cug.edu.cn; Tel.: +86-2767883223
}

Received: 21 October 2020; Accepted: 5 November 2020; Published: 24 November 2020

\begin{abstract}
This study was part of a larger analysis of the framework of sustainable rural livelihoods in the face of urban sprawl in peri-urban rural areas of Mali. Contrary to the existing literature, which has mostly focused on issues of land rights in Mali due to the fact of urbanization, this study analyzed the consequences of urbanization in the city of Ségou on the major sources of livelihoods for residents in the neighboring rural municipality of Sebougou. Three villages in the municipality of Sebougou were selected due to the fact of their proximity to the city of Ségou. We interviewed 120 randomly sampled family heads using a structured questionnaire. The respondents were owners of farmlands or people who had lost their land as a result of urbanization. We analyzed the data using multi-linear and logistic regression models. The results showed that age, occupation, land size, and level of education had significant positive impacts on the farmers' annual family income, while family size and gender exerted negative effects. Low-yield lands and youth emigration increased the likelihood of farmers losing their lands to urbanization. Conversely, land size, yearly income, and age had negative predictive effects on agrarian land loss. The results highlight the need for land management authorities to implement policies to protect agricultural land.
\end{abstract}

Keywords: urbanization; youth emigration; land use; subdivision; agrarian land loss; land reforms; poverty

\section{Introduction}

Effective control of productive resources, especially land, by the rural poor is crucial to their ability to build rural livelihoods and overcome poverty. As a rural development planning approach, sustainable livelihood frameworks are gaining greater attention, as they are a useful conceptual basis for understanding urban poverty as well as the situation of people living in poverty in urban settlements. The effectiveness of this tool in the analysis of the impact of regulations on livelihoods is agreed on by scholars [1].

Today, over half of the world's population lives in urban areas, and the majority of projected growth until 2050 will be concentrated in cities of developing countries in Asia and Africa [2]. On the one hand, urbanization as a factor of development presents positive impacts that transform the fabric of cities morphologically, socio-spatially, socio-economically, culturally, and through knowledge innovation. This metamorphosis provides conduits through which millions of people can transition from poverty to higher levels of productivity, locate job opportunities, obtain a better quality of life through improved education and health care, live in localities with large-scale public investment, and gain access to improved infrastructure and services [3]. Furthermore, with a broader diversity of 
economic opportunities, urban populations can be expected to have a much better standard of living, nutrition, and service delivery than rural populations [4]. On the other hand, urbanization leads to the expropriation of land by violence, because the rural areas surrounding cities are characterized by institutional insecurity, disorder, under-production of economic growth, and incompatibility with modernity [5]. In some ways, uncontrolled urbanization is a source of disorder and poverty. Such kinds of urbanization processes may not cause more sustainable economic growth or substantial change in the foundations of economic growth, because non-agricultural activities may fail to develop at the same rate as urbanization [6].

Urbanization leads to the extension of urban socio-spatial morphologies and infrastructure, which encroach on rural socio-economic activities. This has impacted the livelihoods and quality of life of rural communities who depend on the agricultural sector as their main economic activity. In 2019, the World Bank estimated that the sub-Saharan Africa urbanization rate was $41 \%$ with a projected growth of $78 \%$ by 2050 . Current research suggests that urbanization in sub-Saharan Africa is characterized as urbanization without growth [7]. For example, in the south of Yaoundé city, the State expropriated lands owned by the natives for urban subdivisions. Not all landowners and farmers have the means to undergo the legal process to acquire a title, so land transactions may be informal, written, or oral [8]. Also, in Ethiopia, an increasing number of people are attempting to resolve their housing needs by regularization of land tenure status that is not registered by the administration or the town hall in peri-urban transitional areas [9]. Moreover, in the peri-urban area of Osun State in Nigeria, $72 \%$ of farmers surveyed feared losing their agricultural lands to development projects, as $16.1 \%$ of them had already lost between 1-2 acres of farmland [10]. This worrying trend has led to the escalation of property speculation in peri-urban areas in Central Africa, given the expansion of cities caused by the growth of the urban population. For example, Gbaloko village, located $16 \mathrm{~km}$ northwest of Bangui, had $70 \%$ farmers who lost their land in favor of subdivisions [11].

In Asia, the loss of agricultural land due to urbanization occurs under conditions almost similar to those observed in Africa. In Hanoi, Vietnam, about one-third of agricultural land has been converted into residential areas. Urban growth is accelerating the loss of agricultural land, raising concerns for the provision of food to indigent citizens and peri-urban farmers' livelihoods. Between 1993 and 2000, the acreage of farmland converted into built-up land is the largest with an area of $3856.2 \mathrm{ha}$ [12]. Moreover, in Delhi, India, a multiple linear regression model study showed that housing complexes $(p<0.01)$ and cottage industries $(p<0.05)$ had a significant impact on patterns of agricultural land use [13]. In India, agricultural land loss occurs mainly in states where agrarian land is better adapted than others. Since 2006, the amount of converted farmland is steadily rising [14]. In China's Hang-Jia-Hu region, the alteration of agricultural landscapes to make way for rapid urbanization has reduced the total area of agricultural landscapes in the region (1260665 ha) by 28.5\%, from 1994 to 2003 [15]. In Wuhan city (China), farmers' overall level of well-being in all age groups that have lost their land has declined after land expropriation [16]. In China, farmers who could receive compensation above the standard rate were especially those integrated into the framework of local power [17].

Europe, North and South America as well as Australia, are experiencing this phenomenon. However, unlike developing countries, urbanization is the source of modernization and socioeconomic development in North America and Europe. In the United States, there is a yearly conversion of 500,000 ha of food and fiber production systems [18]. In Canada, research has shown that $60 \%$ of new growth of urban and peri-urban areas from 1988 to 2010 took place on farmland [19]. In Buenos Aires, Latin America, a study based on 30 m resolution Landsat images from June 1985 and July 2015 showed that urban land increased from 0.093 ha to 1.835 ha, and $30.28 \%$ of new urban land originated from lands under production [20]. Urban sprawl in Australia consumed vast land areas for homes, infrastructure, and commercial buildings; nevertheless, land demand remains important [21]. However, the effect of urbanization on agrarian lands is controlled. In Oregon, for example, the conversion of cropland into urbanized areas must consider ecological, social, and economic factors [22]. In France and Portugal, legislation for the maintenance of peri-urban agricultural areas has recently evolved, 
which raises implementation difficulties [23]. In the former communist countries of Eastern Europe, the absence of specific urban policies and urban regeneration plans indirectly led to hypertrophic development and uncontrolled suburban expansion. For example, the city of Bucharest, Romania, has been most affected by these processes determining the transformation of multi-level spaces in the city and the conversion of open spaces to commercial and residential use, affecting both the urban environment and the quality of life of urban-rural communities [24]. In addition, the introduction of the market economy in Slovakia has also led to increasing pressure on the surrounding ecosystems. Moreover, urbanization has also been a major driver of the conversion of productive agricultural land and semi-natural ecosystems into built-up areas, leading to habitat degradation and fragmentation [25].

An increase in the peri-urban population in informal settlements in the cities of Bamako and Segou, Mali, has accelerated poverty and vulnerability to the impacts of climate change [26]. A booming illegal land market has accompanied the expansion of Malian cities. This unregulated market is a major concern for land tenure status and rights in the capital city, Bamako, as well as the regions and prefectures. Agricultural lands are targeted and transformed into non-agricultural uses. At the margins of rapidly expanding and densely populated urban centers, there is a high demand for farmland in an approximate radius of $10-20 \mathrm{~km}$ in the cotton zone of Mali [27]. Given the drastic upsurge in the market value of the land due to the increasing demand in peri-urban areas, land is a valuable economic resource for people who have the money to invest and can generate new revenue opportunities [26]. The conversion of farmland into plots for residential use increases the land value per hectare. Conversion can increase the price a hundred times more than the initial price of the land, and this strongly incites landowners to convert agricultural lands for non-agricultural uses [26]. Bamako's population increased from 658,275 to 1,016,167 between 1987-1997. A high spatial consumption accompanied the high population growth of Bamako, and the land taken over by Bamako dwellers grew from 5208 ha in 1976 to 9889 ha in 1987 and then reached 12,828 ha in 1996 [28]. Since 1995, Bamako has gradually crossed the boundaries; the "spontaneous neighborhoods" extend and join the north villages dependent on the prefecture of Kati [29]. The neighboring villages, with vast land resource potential, have become an attractive area coveted by urban residents leading to the gradual disappearance of land reserves and the need to feed a population with strong growth [28]. In Sebougou, many farmers cooperate with the topographers to make land subdivisions and sell them as plots for housing without authorization from the Regional Directorate of Urban Planning of Segou or the agreement of the governorate. The subdivisions did not provide public places for schools and health centers, which portends problems in the future. Sustainable subdivisions provide for electrification facilities, drinking water, public squares, and socio-sanitary infrastructure.

According to the evolutionary theory of land rights, population growth and market integration are the main forces driving the evolution of standard ownership systems towards private, individual, and family property rights, parallel with the crumbling and disappearance of customary land tenure rights [30]. This evolution has resulted in the demand for formal documentations by private property rights holders, and State actors have mostly responded positively to this request. Thus, over the years, property rights for households and individuals have increased due to the pressure from the rising values of land in Africa [30]. However, this evolution is still only partial, explaining the "imperfect" nature of transforming land into a commodity [31]. Moreover, the conceptual framework for land security and agricultural productivity, developed by Feder et al. [32], illustrates the critical link between the land title and economic performance. Land titles positively affect land security and encourage investment, as they play a vital role in collateral agreements in securing institutional credit. However, this increasing demand for land titles has also resulted in uncertainties about land rights due to multiple ownership claims for the same plots of land, mostly between customary and modern land rights holders [33]. This land insecurity leads to the limitation of the growth of the financial sector because land transactions are not easily carried out, and costs are higher [34]. Thus, the coordination mechanisms for land use are linked to the three governance structures: market, hierarchy, and partnership [35]. In this regime, coordination is carried out within the framework of 
private law rules, deeded to identify and protect individual property rights to facilitate exchanges between legal entities [36]. Four major components characterize experiences in the area of property rights and natural resources management: (1) adoption and recognition of common property rights; (2) transfer of authority and control of land resources management to communities; (3) ecology of the resource itself and the level at which it should be or can be managed; and (4) the importance of market forces in the economic benefits that can arise from the sustainable management of these resources [34]. In post-communist cities, institutional reforms have been primarily accomplished, but the adjustment of urban land use patterns to new societal conditions is still ongoing. Therefore, post-communist cities are still cities in transition. Thus, the market rules on the allocation of resources, the large number of new private owners, entrepreneurs and businesses, and the opening of local economic systems to an international economy have formed the basic requirements for the spontaneous emergence of economic, social, and cultural change [37].

Although there have been several studies on the effects of urbanization in Mali, the majority have focused on land disputes and land rights. However, this study seeks to fill the gap in the literature regarding the adverse social effects of urban expansion in the peri-urban areas of Mali through the loss of agricultural land. It aimed to shed light on peri-urban land issues and the poverty that characterizes it for the adoption of good land policies by the government and local authorities.

\section{Materials and Methods}

\subsection{Study Area}

Sebougou is a municipality in the region of Ségou. Ségou is the third-largest city in Mali, with a population of approximately 200,000. Sebougou was officially created by law No. 96-059 of 4 November 1996, establishing the municipalities. The rural municipality of Sebougou is bounded to the east, west, north, and the south by the urban commune of Ségou, the rural municipality of Konodimini, the rural municipality of Farako, and the rural municipality of Sakoiba, respectively (Figure 1). Youth populations generally dominate the demography of the region of Ségou. In 2015, of a total population of 2.03 million, the $0-15$ age group accounted for $48.5 \%$, 35.3\% were aged $15-39$ years, $11.6 \%$ were in the $40-59$ age group, and those $60+$ accounted for $4.7 \%$ [38]. The main economic activity is agriculture, which faces climatic hazards.

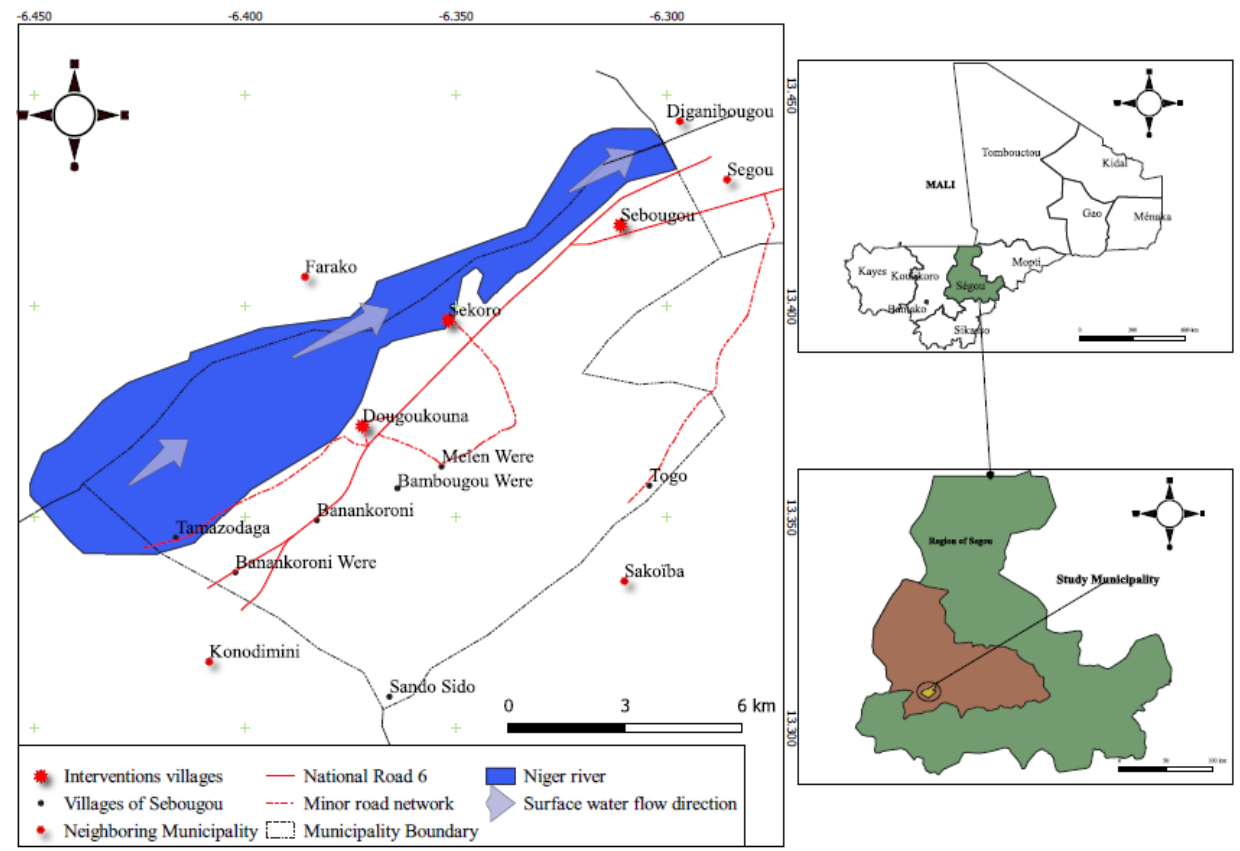

Figure 1. Map of the study area. 


\subsection{Variables}

\subsubsection{Explained Variables}

The sale of agricultural products is the primary source of income for the farmers, and this income is used to manage the overall needs of all family members. Hence, the amount of money earned by a respondent's family annually (in FCFA) from farming activities is a crucial determinant of the level of poverty in the study area. Moreover, the loss of agricultural land is treated as a variable explained by various factors, including the annual income, as presented in Table 1 and described in Section 2.2.2. and Section 2.2.3.

Table 1. Definitions of the variables.

\begin{tabular}{|c|c|c|c|}
\hline Variable & Unit & $N$ & Categories \\
\hline Annual income & F CFA & 120 & $\begin{array}{l}\text { (1) <200,000; (2) 200,000-299,999; } \\
\text { (3) 300,000-399,999; (5) } \geq 400,000\end{array}$ \\
\hline \multicolumn{4}{|l|}{ Socioeconomic } \\
\hline Age & Year & 120 & $\begin{array}{c}\text { (1) } 20-30 ;(2) 31-40 \text {; (3) 41-50; (4) 51-60; } \\
\text { (5) } 61-70 ;(6) 71-80 ;(7)>80\end{array}$ \\
\hline Gender & & & $1=$ Male $0=$ Female \\
\hline Socio-professional structure & & 120 & $\begin{array}{l}\text { (1) Peasant farmer; (2) Gardener; (3) Fisherman; } \\
\text { (4) Sand operator; (5) Caregiver help; } \\
\text { (6) Hairdresser; (7) Plumber }\end{array}$ \\
\hline Family size & person & 120 & (1) $0-9 ;$ (2) $10-15 ;(3) \geq 16$ \\
\hline Migration & & 120 & (1) Yes; (2) No \\
\hline Employment & & 120 & (1) Yes; (2) No \\
\hline Children school attendance & & 120 & (1) Yes; (2) No \\
\hline Family's health care & & 120 & (1) Yes; (2) No \\
\hline Supporting children's education & & 120 & (1) Yes; (2) No \\
\hline \multicolumn{4}{|l|}{ Loss of agricultural land } \\
\hline Land size & ha & 120 & $(1)<1$; (2) $1-4.9$; (3) 5-8.9; (4) 9-12.9; (5) $\geq 13$ \\
\hline Food problem & Family & 120 & (1) Yes; (2) No \\
\hline Land registration & & 120 & (1) Yes; (2) No \\
\hline Victims of urbanization & Person & 120 & (1) Yes; (2) No \\
\hline Mode of access to land & & 120 & (1) Intra lineage access; (2) Purchase \\
\hline Compensation & & 72 & (1) Yes; (2) No \\
\hline Land loss due to low yield & & 120 & (1) Yes; (2) No \\
\hline
\end{tabular}

\subsubsection{Control (Socioeconomic) Variables}

Independent variables, such as gender, age, occupation (in addition to agriculture), and the level of education of a household head, significantly determine the level of income of a family in farming communities [39]. The level of education of the farmers can be an advantage in the proper management of land to extract maximum benefit. Moreover, having other forms of occupation aside from farming may increase family income. In addition, family size, which refers to the number of persons living within the same family and working together on the same property, can influence the income of a family [40]. Additionally, we hypothesized that health care for family members and the ability of farmers to cater for children in school are indicators of the financial capacity of the respondent and, hence, could predict a family's income [41].

\subsubsection{Explanatory Variables for Agricultural Land Loss}

Migration involves families with one or more members on exodus or abroad in search of wealth. Based on experience in Mali, family lands are usually sold to support a family member who migrates to seek a better future. While this leads to the loss of farmlands, it could also bring financial benefits if the emigrant succeeds. Moreover, families with vast lands usually sell a portion to solve family problems. Thus, we selected land size, defined as the number of hectares of arable land belonging to 
each family, as both a predictor of family income and the loss of agricultural land. As a result of urban expansion, some farmers have lost part or all of their agricultural lands; such farmers are described as the victims of urbanization in this study. Food problems highlight the number of families who have food problems due to the fact of poverty or arable land loss. Moreover, there is the likelihood that farmers sell their farmlands that are relatively unproductive or give low yield. Land registration means land with titles granting the right of ownership. Farmers who have no land titles are likely to sell their lands for fear of losing them to the government or private institutions. The mode of access to land is the route by which it is possible to obtain a plot of land to earn their keep. Compensation means farmers who had been compensated for a loss of agricultural land. Only 72 of the farmers were real owners of the lands and were, thus, eligible for compensation (see Table 1).

\subsection{Models}

Statistical methods have been applied to various land use studies. They are usually employed to explore the relationships among variables through linear regressions, logit models, and logistic regression models $[13,42,43]$. An advantage of these approaches is that they can readily identify the extent of influence an independent variable exerts and the confidence levels regarding their contribution [43]. This study used two models, namely, the multiple linear regression and the logistic regression models, to analyze our data. In both cases, multicollinearity was assessed using two collinearity statistics: the variance inflation factor (VIF) and tolerance values [44]. The multiple linear regression model (Equation (1)) was used to determine how the socioeconomic variables predicted the annual income of the farmers.

$$
Y=\alpha+\beta_{1} x_{1}+\beta_{2} x_{2}+\ldots+\beta_{9} x_{9}+\varepsilon
$$

where $\mathrm{Y}$ indicates the respondent's income; $\mathrm{x}_{1}, \mathrm{x}_{2}$, and $\mathrm{x}_{3}$ represents age, the socio-professional structure, and land size; $x_{4}$ means the level of education; $x_{5}$ indicates family size; $x_{6}$ indicates food problem; $x_{7}$ is the gender; $x_{8}$ denotes the family member in migration; $x_{9}$ stands for land registration. Furthermore, $\alpha$ denotes the constant, $\beta_{1}, \beta_{2} \ldots \beta_{9}$ indicate the respective coefficients of the independent variables, whereas $\varepsilon$ is the error term in the model.

The logistic regression model, described by Equation (2), was used to examine how various variables influenced the likelihood of farmers being victims of urbanization.

$$
\ln \left(\mathrm{P}_{\mathrm{x}} /\left(1-\mathrm{P}_{\mathrm{x}}\right)\right)=\beta_{0}+\beta_{1} \mathrm{X}_{1 i}+\beta_{2} \mathrm{X}_{2 i}+\ldots+\beta_{k} \mathrm{X}_{k i}
$$

where the subscript $i$ is the $i$ th observation in the sample; $P_{x}$ is the probability of an event occurring for an observed set of variables $\mathrm{X}_{1} ; \mathrm{P}_{\mathrm{x}}$ is the probability that the farmer is a victim of urban expansion. $\beta_{0}$ is the intercept term, and $\beta_{1}, \beta_{2} \ldots \beta_{k}$ are the coefficients of the explanatory variables $X_{1}, X_{2} \ldots X_{k}$.

\subsection{Data Collection}

Our survey involved three villages in the rural municipality of Sebougou: Sebougou, Sekoro, and Dougoukouna. On the one hand, they were chosen based on their proximity to the city of Ségou and their ease of access, as they are connected by a major road network (RN6). On the other hand, the urban project development of Ségou will involve the construction of a new bridge across the Niger River between Sebougou and Sekoro; this motivates people to settle on agricultural land. In each of the three villages, 40 people are randomly chosen to answer questionnaires using a list of heads of families of villages provided by the town hall. Our sample consisted of 120 respondents, among residents who owned agricultural land or whose land was lost due to the fact of urban expansion. The survey was conducted in February 2019. The majority of the people interviewed were male as most households, and thus land tenures, are patriarchal. Also, in the presence of men, women did not want to discuss any questions relating to agricultural land. Hence, to avoid the influence of men on women's reactions 
that could affect the results, we administered the questionnaires to female respondents in the absence of men.

The demographic characteristics of the respondents showed that most $(88.3 \%)$ of our respondents were males, with $11.7 \%$ being female. It is worth noting that 11 out of the 14 women were widowed. The average age of the respondents was 56.6 years ( $\mathrm{SD}=1.8$ years), as shown in Table 2 , with $40.0 \%$ of the respondents aged above 60 years. The majority were either gardeners $(54.2 \%)$ or farmers $(35.0 \%)$, with the remainder being fishermen, sand operators (2.5\%), caregivers, hairdressers, and plumbers. Most (95.8\%) of them were illiterate, as only $4.2 \%$ had some form of education, either college or primary school. The average family size was 13.4 persons $(\mathrm{SD}=0.5)$. Most $(68.3 \%)$ of the respondents had a family size of $10-15$ persons, with $24.2 \%$ having 16 or more persons in the family. The families earned an average of FCFA 222,500 (SD = FCFA 13,266) annually.

Table 2. Average age, family size, land size, and annual income of respondents.

\begin{tabular}{ccc}
\hline Variables & Mean & SD \\
\hline Age (y) & 56.6 & 1.8 \\
Family size (person) & 13.4 & 0.5 \\
Land size (ha) & 4.54 & 0.59 \\
Annual income (FCFA) & 222,500 & 13,266 \\
\hline
\end{tabular}

\section{Results}

\subsection{Consequences of the Urban Expansion of Ségou on the Municipality of Sebougou}

The results of the multiple linear regression model, based on Equation (1), are presented in Table 3. Generally, the multicollinearity among the independent variable was acceptable [44], as the average VIF and tolerance were 2.335 (VIF < 10) and $0.541(>2)$, respectively. According to the results in Table 3, the urbanization of the city of Ségou has negatively impacted the social capital of the neighboring municipality of Sebougou. The coefficients of four variables-age, socio-professional structure, land size, and level of education-were $0.629,0.639,0.122$, and 0.739 , respectively, and they were statistically significant $(p<0.05)$, indicating their positive influences on the income of the farmers in the municipality. Conversely, family size and gender showed a statistically significant but negative influence ( $\beta=-0.485$ and $\beta=-0.442$ ) on income. This implies that, although larger families could have a larger labor force to work on farms, other factors, such as land size, may limit a family's ability to generate income from farming activities. The negative coefficient of gender implies that women have less income. This could be attributed to the tradition of the area, which indicates that women do not own land. Hence, women do not have large agricultural lands, which limits their income. Moreover, tradition also puts the responsibility of taking care of the family on the man. From the survey, 78 farmers $(65 \%)$ indicated that their incomes were low, and no farmer had an annual income reaching 1 million FCFA. A total of 42 (or 35\%) of the respondents had an annual income below 200,000 FCFA. The overall poverty line is estimated at FCFA 171,810 per capita per year in Mali [45]. Mali mirrors Sen's view regarding poverty. Poverty is a failure to reach a minimum capability threshold, and the capability constraint is absolute. However, capability is not fixed over time or in societies. The term "absolute" means that there is a threshold beyond which functioning within society is not possible [46]. According to Sen, poverty should be considered as basic capabilities deprivation, and this deprivation limits a person's freedom to pursue their objectives in life. 
Table 3. Impacts of selected variables on income.

\begin{tabular}{ccccc}
\hline Independent Variables & \multicolumn{2}{c}{ Coefficients } & $t$ & $p$-Value \\
\hline \multicolumn{1}{c}{$\boldsymbol{B}$} & Std. Error & & \\
\hline Age & $0.629^{* * *}$ & 0.054 & 11.646 & 0.000 \\
Socio-professional structure & $0.639^{* * *}$ & 0.076 & 8.385 & 0.000 \\
Land size & $0.122^{* *}$ & 0.042 & 2.896 & 0.005 \\
Level of education & $0.739^{* * *}$ & 0.180 & 4.102 & 0.000 \\
Family size & $-0.485^{* *}$ & 0.156 & -3.101 & 0.002 \\
Food problem & -0.150 & 0.109 & -1.383 & 0.170 \\
Gender & $-0.442^{* *}$ & 0.168 & -2.633 & 0.010 \\
Family member in migration & 0.058 & 0.109 & 0.536 & 0.593 \\
Land registration & 0.751 & 0.502 & -1.496 & 0.138 \\
(Constant) & -1.428 & 0.496 & -2.878 & 0.005 \\
\hline
\end{tabular}

Note: Dependent variable: Annual income; Model $R^{2}$ (Adjusted) $=0.718, F=34.6, p<0.001$; ${ }^{* * *}$ and ${ }^{* *}$ denote that the coefficient is significant at $1 \%$ and $5 \%$ levels, respectively.

The loss of farmland increases the unemployment rate. In addition to climate change, the rainfall deficit resulting in poor harvests encourages the departure of young people. Thus, encroachment on agricultural land as a result of urbanization reduces agricultural lands by decreasing agricultural productivity and creates a deficit in the market supply, leading to the rural exodus [47]. These young people usually go to gold panning sites or Europe through challenging conditions by risking their lives. They hope to earn an instant fortune in these areas, which is still not certain. Remittances help to support households, although some families have lost contact with migrants [48]. The migratory phenomenon also has an impact on the loss of agricultural land. Farmers pushed by their children, sell their land for foreign travel expenses. The elderly staying in the village after the departure of the young are, in most cases, forced to sell the land because they can no longer exploit it. Poverty emerges in the villages, and the young people tempting fate sometimes turn to banditry and drugs.

Presently, like a scourge, poverty affects almost all the farmers in the rural municipality of Sebougou, especially those in the village of Sebougou, who have lost most of their lands. In Mali, $57.9 \%$ of rural households describe themselves to be poor compared to $46.6 \%$ for the urban environment [45]. Older people are the most affected by societal developments, including the process of converting agricultural lands, industrialization, and urbanization. They are too old to obtain a stable and well-paid job in the industrial sector because they do not meet the requirements of companies [49]. The manifestations of poverty include the inability to meet basic needs. In Sebougou, Sekoro, and Dougoukouna, 53\% (64) of our respondents reported food insecurity. The annual productions cannot support the needs of the population. Similarly, in Bahir Dar city in Ethiopia, holders of the precarious land tenure system are exposed to competing claims. They are severely compromised in their ability to procure sufficient food and sustainable livelihoods [50]. Also, in Wuhan, China, research shows that the overall well-being levels of farmers who have lost their lands due to the fact of urban growth declined, and farmers aged 45-65, under 45 and over 65 had levels of welfare which decreased by $18.7 \%, 16.6 \%$, and $12.7 \%$, respectively [16].

The majority $(90 \%)$ of the residents indicated that their children do not attend school. Despite the presence of schools and literacy centers in all of the villages in the municipality of Sebougou, many parents remain hostile to school and literacy because they believe that their children have no future in attending school. This attitude is old-fashioned and implies that the education rate is very low, and many children enrolled drop out of primary education. As noted earlier, only $4 \%$ of respondents were literate compared to 115 who did not attend school. Education provides an opportunity for a person to escape poverty, to find a job, to improve their living conditions, and to make informed choices. In Mali, a survey reported a negative correlation between the level of education of the family chief and the incidence of poverty: $6.1 \%$ against $50.8 \%$, respectively, for a level of education equivalent to that of the superior compared to that which was without educational attainment [45]. The study also 
revealed that the poor are less literate in all regions compared to the less poor. For example, in Thuy Duong, Vietnam, farmers who lost their farmlands had no vocational training [49].

Moreover, most $(89.2 \%)$ of the respondents indicated that they could not take care of family health problems. The majority of people use traditional medicine and street drugs to treat common diseases such as malaria. These counterfeit medicines create a real health problem within the population. So, poverty causes people to move towards the cheapest medications. Almost all households use charcoal as the primary source of energy for cooking. The use of wood fuel seems to be much more of a phenomenon of poverty.

\subsection{Causes of the Loss of Agricultural Land in Sebougou Facing the Urbanization of Ségou}

Human capital (labor capacity, lack of education), financial capital (income from farming), and social capital (tradition and discrimination against women) affect the loss of agricultural land. The variables used were land size, the level of education, land title ownership, annual income, gender, land loss due to the fact of low yield, youth out-migration, and age.

Table 4 presents the results of the effects of the variables on the dependent variable-victims of urbanization. The average values of VIF and tolerance of the model's predictors were 2.499 and 0.545 , indicating that the level of multicollinearity in the model was generally acceptable [44]. The sign of the coefficients $\beta$ indicates the direction of the relationship (Equation (2)). The classification table (Table 5) gives an overall percentage of $97.5 \%$, which implies that the model (Step 1) adequately explains our data. From Table 4, land size, annual income, and family size negatively predict the loss of farmlands owing to urban expansion $(p<0.05)$, implying that they inversely influence the likelihood of farmland loss. Conversely, age and land loss due to the fact of low yield was statistically significant $(p<0.05)$ and had positive predictive effects on the victims of urbanization. Youth out-migration also showed a significant positive effect but at the $10 \%$ significance level. The respondents lost an average of 4.5 ha $(S D=0.8 \mathrm{ha}) ; 15 \%$ of them lost at least 9 ha of their land. Three-quarters $(75 \%)$ of the respondents, in the villages of Sebougou, Sekoro, and Dougoukouna, lost their lands due to the fact of low yield. The low yield and low incomes of farmers are one of the main reasons for the sale of farmlands. The main activity is agriculture, subject to the rhythm of climatic hazards. The main crops are millet, maize, and sorghum and are characterized by poor harvests due to the fact of either the lack of rainfall or unpredictable precipitation patterns.

Table 4. Effects of variables of agricultural land loss.

\begin{tabular}{ccccccc}
\hline Variables & $\boldsymbol{\beta}$ & $\boldsymbol{p}$-Value & $z^{2}$ & Exp $(\boldsymbol{\beta})$ & \multicolumn{2}{c}{ Collinearity Stats. } \\
\cline { 5 - 7 } & & & & & Tolerance & VIF \\
\hline Land size & $-3.321^{* *}$ & 7.777 & 0.005 & 0.036 & 0.746 & 1.341 \\
Level of education & -14.221 & 0.000 & 0.999 & 0.000 & 0.534 & 1.874 \\
Land title ownership & 1.379 & 0.000 & 1.000 & 3.969 & 0.826 & 1.210 \\
Annual income & $-7.068^{* *}$ & 6.516 & 0.011 & 0.001 & 0.410 & 2.438 \\
Gender & -3.622 & 0.339 & 0.561 & 0.027 & 0.562 & 1.779 \\
Land loss due to low yield & $4.981^{* *}$ & 6.382 & 0.012 & 145.655 & 0.712 & 1.404 \\
Youth out-migration & $3.198^{*}$ & 3.545 & 0.060 & 24.479 & 0.732 & 1.367 \\
Age & $3.664^{* *}$ & 7.656 & 0.006 & 39.013 & 0.149 & 6.731 \\
Family size & $-16.931^{* *}$ & 6.299 & 0.012 & 0.000 & 0.230 & 4.352 \\
Constant & -22.982 & 0.000 & 0.000 & $9.570 \mathrm{E} 9$ & & \\
\hline
\end{tabular}

Note: Dependent variable: Are you a victim of urbanization?; Model's $\chi^{2}=137.706(p<0.001),-2 L L=23.817$, $R^{2} \mathrm{CS}=0.683, R^{2} \mathrm{~N}=0.923$; ${ }^{* *}$ and * denote that the coefficient (or Wald statistic) is significant at $5 \%$ and $10 \%$ levels, respectively. 
Table 5. Classification table.

\begin{tabular}{ccccc}
\hline & & \multicolumn{3}{c}{ Predicted } \\
\cline { 3 - 5 } Observed & & $\begin{array}{c}\text { Are You a Victim of Urbanization? } \\
\text { No }\end{array}$ & Yes & Percentage Correct \\
\hline Are you a victim & No & 46 & 2 & 95.8 \\
of urbanization? & Yes & 1 & 71 & 98.6 \\
\hline \multicolumn{2}{c}{ Overall percentage } & & & 97.5 \\
\hline
\end{tabular}

Farmers with insufficient income generally sell their land to meet their needs. The results show a negative relationship between gender and land loss, although it was not significant. However, gender adversely affects women because, according to tradition, women do not own land, but develop small plots of land offered by men which they can lose at any time. In the municipality of Sebougou, some farmers have given up poor agricultural land at the expense of more fertile land because of low yield. According to the Land Ordinance of 2000, only the cultivation of a customary land gives its holder the right of use, and the non-development or cultivation of customary land leads to its loss. The migration of young people leads to the departure of the labor force. Some peasants sell the land to support young people to engage in the adventure. Older people who stay in the village after the young people leave, tend to sell the land to solve the family's problems while waiting for their child to send them money from abroad. Moreover, family size has a significant negative influence on the likelihood of land loss, suggesting that smaller families have a higher probability of losing their lands and vice versa. This is probably because, due to the fact of political reasons, local authorities are usually cautious when targeting the lands of large-sized families, as they fear losing substantial votes during elections. Also, based on our experience, smaller families are mostly not natives of the area, so they have relatively little power or influence.

To meet the multiple needs of their families, many farmers in Sebougou took advantage of the vicinity of Ségou to subdivide their lands for sale for residential use. The large peri-urban areas consist of patterns of use of informal land, lack of infrastructures, poor or non-existent public services, inferior housing, and families living in poverty [3,50]. To subdivide their lands, some farmers go through administrative procedures respecting all the rules of the subdivision. In that case, the land sold is registered, and the sales contracts are lodged at the land registry. These lands are expensive and usually do not suffer any problems. Besides, the size of the land has a positive relationship with its loss because farmers with a lot of farmland tend to sell part of their land to make money. Some scholars have reported a negative correlation between the amount of cultivated land and socioeconomic development and urbanization in developing countries in Asia and Africa [14,51,52]. This implies that the total amount of cultivated land decreases with the improvement of urbanization. Other landowners in Sebougou, for fear of the extent of the phenomenon of urbanization, sell their lands without consulting the authorities.

In Sebougou, Sekoro, and Dougoukouna, 15 farmers claimed to have sold their lands, estimated at over 40 ha, for fear of losing them to the State, a private institution, or a wealthy person. Although the land tenure code on private and state-owned land of 1986 recognizes customary rights and compensation procedures in the case of expropriation of land by the government, evidence of compensation paid is rare in practice [26]. The number of farmers compensated following the official subdivision in Sebougou was 21, and they were all dissatisfied with the compensation package. As a result of urban expansion, large families that do not have adjoining plots were compensated only once. These families were not compensated again when other lands they owned were affected. Also, some farmers with small plots were not rewarded. Indeed, there was no set compensation criteria. Farmers who had lost 5 ha received one plot $(0.05 \mathrm{ha})$ or at most two plots $(0.10 \mathrm{ha})$ as compensation. In addition, farmers who received no compensation cultivated lands that had been loaned to them by other villagers to support their subsistence life. It was only the real owners who were compensated. For this purpose, 
farmers working for decades on land have been dispossessed without compensation because they were not the real owners. Indeed, the compensations comprised one or two plots for residential use. Land speculation is one of the causes of land loss. This practice exists in Nigeria where, in the urban suburbs of Lagos, more than $80 \%$ of the respondents asserted the prevalence of informal tenure rights on the margins, which would also be a major cause of excessive acquisition of land [53].

These practices can also be observed in other African villages. For example, in Gbaloko village, $16 \mathrm{~km}$ north-west of Bangui, real estate speculation is intensifying with the expansion and growth of the urban population, and $70 \%$ of farmers have lost their land in favor of subdivisions [11,50]. It is also possible that with effective land allocation mechanisms, there are fewer land-related conflicts, and, therefore, these areas tend to receive a large influx of immigrants [54]. Also, in Ethiopia, the land is owned by the State, and permanent property transfers following sale are prohibited by the constitution because, in peri-urban areas, landowners are only allowed to use the land for agricultural purposes. Nevertheless, the unauthorized fragmentation of farmlands and their sale is widely practiced in peri-urban areas adjacent to major cities [50]. Thus, according to a village councilor from Sekoro, many villagers have already sold a large part of their family lands secretly. Our survey identified 38 $(95 \%)$ respondents in the village of Sebougou who had no more cultivable land. Land sold as a result of private subdivisions had less value because, due to financial reasons or the fear of expropriation, the farmers sold it at a low cost and were not satisfied. Land sale has become an easy way to earn money, especially due to the high demand by urban populations (officials coming from elsewhere, traders, etc.). For example, the populations of the south-central region of Cameroon, called Bétis, were selling their lands because of land insecurity, expropriation by the government through subdivisions, and difficulty in obtaining land titles [8].

\subsection{Change in Use of Agricultural Land and Loss of Family Farms}

The natural capital of the Municipality of Sebougou changed, giving rise to landless farmers and modifying access to common property resources. A total of 72 farmers, representing $60.0 \%$ of the respondents, admitted to being victims of urbanization. Our investigations revealed that official urbanization had affected 577.5 ha, more than half of which is arable land in the village of Sebougou. An example is the construction of the Modibo Keïta's factory (Grand Distributeur Céréalier du Mali, GDCM) (Figure 2), which affected more than 6000 households. The factory is a large cereal distributor in Mali and covers an area of approximately 7 ha 1538, with eight land titles (Land title No. 1133 to 1140). The results also show that prior to urban expansion in Sebougou, the ratio of agricultural land per family was 5.5 ha. With urban expansion, this ratio decreased to 0.1 ha. Also, in Sekoro, urban expansion resulted in the decline of the ratio of agricultural land per family from 4.3 ha to 2.0 ha. Moreover, in Dougoukouna, the ratio of agricultural land per family was 5.5 ha before urban expansion; however, it has decreased to 4 ha per family. The ratio of agricultural land per family decreased from remote villages to the urban center.

The situation in Sebougou is similar to reports from some formerly socialist countries, like Romania, the Czech Republic, and Slovakia, where the cities' expansion encroached on neighboring agricultural lands, turning the affected peri-urban areas into a mosaic of built-up environment and agricultural land [55-57]. Consequently, the land available for agricultural use became limited, inconveniently shaped and scattered, and, therefore, often considered economically inviable for farming. Hence, it was either abandoned or further turned into built-up areas. For example, on the edge of Bucharest, Romania, an analysis of data from 2002 to 2013 (11 years) showed that land abandonment is a potential precursor to built-up development [55]. Also, in the Czech Republic, the most significant change is developing built-up areas on agricultural land. For example, from 1824 to 2016, the built-up area in the Modřice and Dolní Věstonice areas expanded from $70 \%$ to $90 \%$ to agricultural lands [56]. Unlike Sebougou, where agricultural land loss is the most critical issue, forest landscape reduction was the most pronounced effect in countries such as the Czech Republic, Hungary, and Slovakia. However, 
similar to Sebougou, Romania's most remarkable changes were the decrease in arable land and the enlargement of areas of complex cultivation patterns [57].

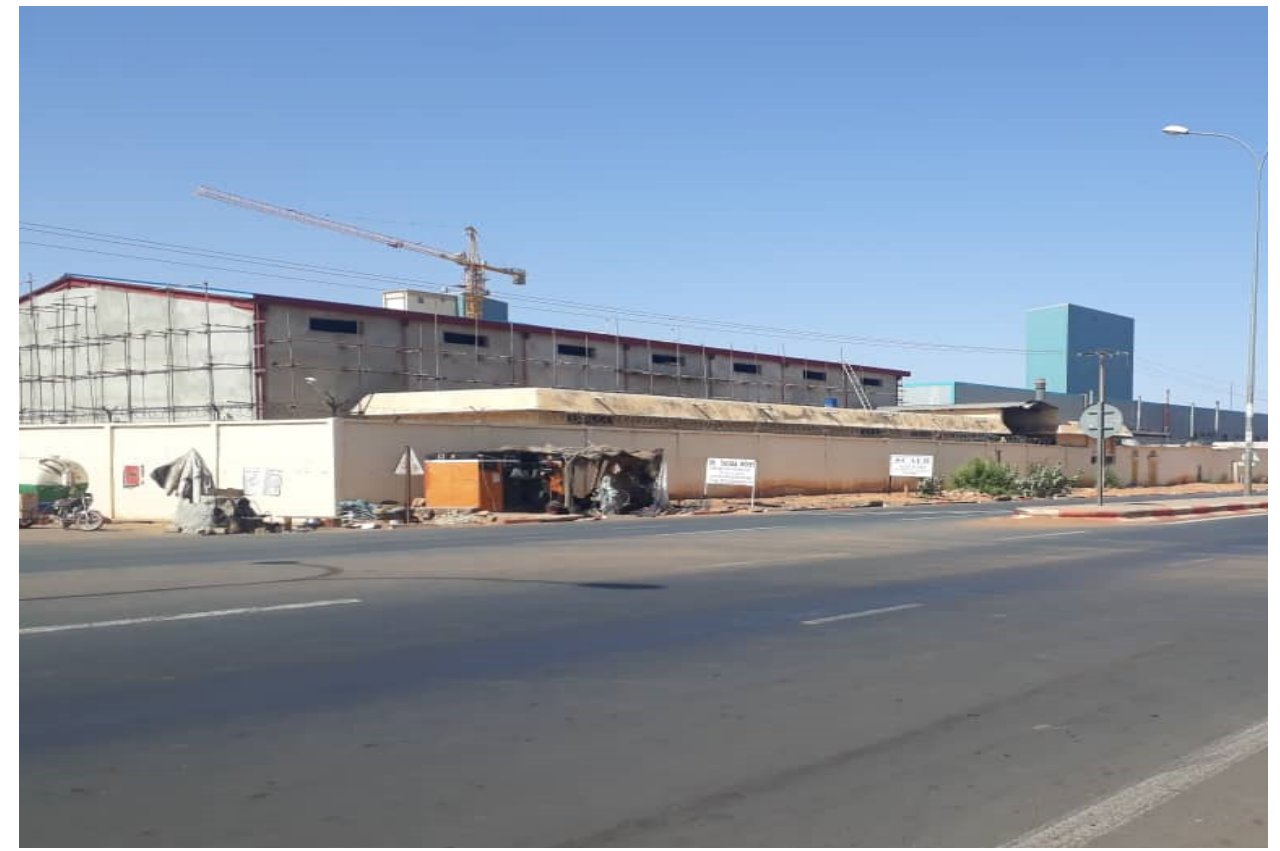

Figure 2. Food processing plant (Grand Distributeur Céréalier du Mali) located on the farmland of Sebougou.

Investments in infrastructures can generate positive returns in terms of development and poverty reduction and contribute to job creation in agriculture and other sectors [58]. Unfortunately, GDCM employs only a small number of young people from the municipality. In the forecasts of the urban master plan, some infrastructure is already located in the area of Sebougou: a bus station for heavy-load trucks (15 ha), technical high school complex (Central School for Industry, Commerce, and Administration) (5 ha), the Central School for the Textile Industry (60 ha), the town hall (0.05 ha), cemetery No. 1 (10 ha), cemetery No. 2 (0.25 ha), a muddy mosque (0.04 ha), and a permanent mosque structure (0.25 ha). For this purpose, Lasisi et al. [10] reported that farmers in the vicinity of city areas are losing their lands for various development projects, without compensation or regard for their food production and livelihoods. Moreover, in the villages of the municipality of Sebougou, private land subdivisions transformed the remainder of the land after the official urbanization to houses, by almost destroying the grain production completely. Furthermore, in Ethiopia, approximately 78\% of informal plots are purchased from legitimate local and peri-urban landowners [50]. Generally, land loss has led to a decline in agricultural production and contributed to increasing unemployment, rural-urban migration, poverty, and the abandonment of traditional practices. However, in rural Ghana, the conversion of first-choice farmland into other land uses was considered profitable for agricultural expansion [51].

The reduction in agricultural land has led to a considerable decrease in agricultural production. The municipality of Sebougou was a large producer of cereals but other municipalities now supply it because the production no longer meets the needs of the population. Doing so, the population purchases rice, millet, or other food products thanks to market gardening on the banks of the River Niger, which, moreover, does not satisfy all the food needs. A 2015-2016 report of Ségou's agricultural sector mentioned that cereal production losses related to official urbanization were estimated at 1833.5 tons (all dry cereals combined). The loss of production due to the subdivision of private lands was estimated at 508.28 tons. The total area of private subdivisions (not mentioned in the official urbanization documents) was 508.28 ha (area obtained by Geographic Positioning System). 
These lands, being a little distant from the villages, were only used for millet and sorghum crops. The total loss of sorghum and millet was estimated at 2841.28 tons per year. While the existence of a more dynamic and benefiting agricultural sector would be likely to dramatically reduce rural poverty and enable countries to achieve the Millennium Development challenge of halving poverty and hunger (Banque Mondiale, 2008). Some developed countries, such as Canada, have observed the same scenario. In Canada, the continued expansion of cities consumes high-quality farmland, resulting in many direct and indirect consequences: loss of production, increased cost of inputs on less fertile land, high additional transport costs to supply the market with products, and the loss of ecosystem services [18].

\section{Discussion}

\subsection{Impact of Land Management Crises on Rural Livelihoods}

The drastic loss of livelihoods, including agricultural land in the peri-urban areas of Sebougou, is largely related to the crisis in Mali's land management system. Mali's land legislation recognizes various categories of land rights, with particular emphasis on private property. For example, the 2000 Land Code (Code Domanial et Foncier) recognizes customary rights exercised collectively or individually on unregistered land. According to the Code (Chapter 3, Section 1, Article 45), when the rights, as mentioned above, include a regular development (land regularly cultivated), these rights can be granted, in whole or in part, to any person or converted into a property right for the benefit of the holder. Additionally, Title 4, Chapter 2, Article 76 of the Agricultural Land Orientation 2006 (Loi d'Orientation Agricole) recognizes customary rights. Some of the provisions in the legislation are ambiguous and, hence, serve as a source of conflict or abuse. Ultimately, they increase land insecurity. For example, while the Land Code acknowledges customary rights, it classifies lands with the said rights as private State property and provides overarching guarantees to these rights, including the application of the expropriation procedure in the public interest. This creates a permanent state of tension between these two principles, which is generally unfavorable on the exercise of customary rights.

Ordinance No. 00-027/P-RM of the Land Code ratified, amended by Law No. 02-008 of 12 February 2002, provides in Article 169 that only a land title acquires land ownership which is final and unassailable. In addition to land access through land title and customary rights, the Land Code 2000 defines other modes of access to land, including rural concession, sale, rental, emphyteutic lease, or allocation. Moreover, the lack of wide access to land formalization processes in high-pressure areas may promote those with power, information, and resources [59]. Similarly, with a hybrid system of land tenure administration (customary and statutory), in Accra, Ghana, approximately 2100 ha of agricultural land was converted to urban use annually between 1990 and 1993, and these numbers are still rising. These trends are attributed to the existing customary tenure system, which allows landowners to virtually decide what uses they want to make of their plots by dictating the composition of land-use plans [60]. Essentially, customary rights only give its holder a right of use. Meanwhile, the formalization of such rights into land title rights is characterized by complex and costly procedures that exclude the great majority of rural people from official land ownership [61]. A study [62] conducted in Buenos Aires, Argentina, showed that land titles could be an important tool for poverty alleviation, not through the shortcut of access to credit, but through the slow investment in the human and physical capital which should help alleviate poverty for the next generations. Conversely, in Mali, research indicated that land tenure security arrangements in a peri-urban environment, where land commodification led to strong competition, offered little incentive for investment [63].

The situation mentioned above has created land tenure insecurity leading to the loss of agricultural land and decreased the means of sustenance for the majority of the population. Land tenure insecurity stems from any activity, practice, policy, legislation, etc. (written or unwritten, real or perceived) that threatens the rights and freedom of landowners. Then, land rights are secure if they are not contested or, in the case of contestation, they need to be confirmed by public authorities, whether customary, 
governmental, or both [64]. Indeed, due to the increasing human pressure on land and natural resources, anarchic urbanization, and the introduction of new values in rural areas, rural land tenures are undergoing profound changes. Rural land is mostly unregistered, and very few rural people, for various reasons (e.g., high cost, long and complex procedures), have land titles that confer legal ownership and security. Hence, in Mali, especially in the peri-urban areas, farmers who cannot afford the cost of obtaining a land title start selling their lands because, according to the statutory law, untitled lands belong to the State. Similarly, research in Faisalabad, Pakistan, showed that from 2006 to 2015, the size of land ownership decreased significantly from 5 acres to 2 acres due to the sale of land for housing projects [65]. In contrast, in Japan, cultivated land declined over the past three decades. In the 1990s, Japan lost cultivated land at the rate of $1 \%$ per year due to the fact of poor profitability. Also, the National Resources Conservation Service in 2003 reported that the United States lost its farmland at a rate of $0.1 \%-0.3 \%$ per year due to the fact of development. In most European countries, the utilization of agricultural areas decreased between 1975-1995, and the national figures showed trends ranging from $-12 \%$ and $-1.5 \%$ in the United Kingdom and Luxembourg, respectively [66]. Thus, according to the national statistics of China, after the year 2000, the main reason for the reduction in cultivated land was the national "Grain for Green" program launched in 1999. Between 2000-2003, almost $70 \%$ of the total decrease in cultivated land was through the fallow program [66].

\subsection{Effects of Decentralization and the Creation of Rural Municipalities}

The violent political change that took place in Mali in 1991 led to the establishment of democracy and a multi-party system. Among the major political and administrative reforms that followed this event was decentralization. For this purpose, Law 96-059 of 04 November 1996, saw the creation of 701 municipalities. However, the territorial divisions did not take into account land ownership regimes. Consequently, natural resource management in the country is subject to a plurality of contradictory standards and practices between the main (statutory and customary) actors in land administration. This situation threatens the existence and functionality of new decentralized entities and has resulted in land disputes. A recent report [67] indicates the most serious land problems in Mali such as land grabbing $(23 \%)$, land ownership/use disputes $(20 \%)$, disputes over limits $(16 \%)$, disputes over title to property $(13 \%)$, and disputes over rites of passage $(11 \%)$, etc.

After the decentralization, most newly elected mayors target, subdivide, and sell customary lands, as plots for housing, to shore-up the municipality coffers. To that effect, many farmers without land titles have lost portions of or their entire farmlands. We could, therefore, say that land decentralization is still theoretical if the legal text necessary to implement the transfer of different domains or their management to local authorities is absent. Also, decentralization is at the root of many conflicts between traditional authorities who managed the land according to custom and mayors based on formal law. Similarly, in Indonesia, disputes over customary land ownership rights keep arising in the era of decentralization and democracy [68]. Additionally, the challenge of multiple actors involved in the land allocation system, without adequate control and consultation measures, has encouraged land speculation and other abuses from some state officials. Moreover, customary land policies governed by customary law and national law often give rise to disputes. Marta et al. noted further that there is no synchronization and harmony between the sectoral laws and the basic principles of agrarian law, regarding the management of natural resources in Indonesia. In addition, the government has not yet created policies at the local level regarding the protection and recognition of customary lands [68].

To circumvent the sale of land from mayors, many farmers of the municipality of Sebougou prefer to sell their lands and, generally, at low prices because these lands are not registered. Sometimes, irregular subdivisions are initiated in peri-urban areas by customary authorities or landowners. These poorly planned operations often lead to inadequate developments encroaching on the public domain and the land rights of other citizens. 


\subsection{Impacts of IMF and World Bank Policies}

Property rights influence economic growth in different ways. When property rights are guaranteed, it can increase the incentive for households and individuals to invest and, in many cases, it can also facilitate getting credit which can allow not only to make these investments but also to benefit from a kind of insurance in the event of shock [69]. Security of tenure rights further facilitates low-cost transfers through rent or sale, which improves land allocation while promoting the development of financial markets. It was in this context that the International Monetary Fund (IMF) and the World Bank imposed on poor African countries a policy that promoted the privatization of land rights in societies dominated by the customary management of land because land is inalienable according to tradition. Thus, customary land tenure, linked to a specific type of economic organization, has evolved considerably with the monetization of economic relations, resulting in an increasing land market value; and new land rules have been enacted [28]. For that purpose, the desire to earn easy money has led many farmers from Sebougou to sell their land. In Ghana, a study [51] showed that 39\%, representing the majority of respondents, reported that economic reasons would prompt them to convert their farmland to other non-farm uses. Thus, low agricultural yields due to the loss of soil fertility and the high cost of agricultural inputs, such as fertilizers, seedlings, and farm tools, make it difficult for poor farmers and smallholders to practice intensive farming, in addition to land-use changes due to the deterioration of the livelihoods of landowners. By so doing, farmers tend to give up their land for other activities when faced with financial hardship in exchange for financial gains.

\subsection{The Limits of Land Reforms}

The interest in securing the means of livelihood, including land, has led the government to undertake reforms including that of the Land Code of 2000 and the most recent, which led to the adoption of the Agricultural Land Law of 2017. These reforms did not lead to the expected results because land tenure issues continue to be topical in Mali. For example, if customary rights are recognized by the formal law, they cannot be currently registered because the decree that should specify the terms of their recognition has not been adopted yet three years after the adoption of the Agricultural Land Law 2017. Indeed, for the proper functioning of land management, the decree must be adopted and implemented without delay [59]. Also, the widespread ignorance of land legislations among the population and often misinterpretations from state officials and locally elected officials are causes of livelihood losses. In the world, the best plans are useless if they are not integrated into the processes that guide the expansion of factories, subdivisions, and roads. Therefore, the challenge to the sustainability of agricultural activities lies in the conservation and management of existing fragments in the face of very rapid urbanization. This can be achieved through the integration of agricultural landscapes into urban planning systems and agricultural land must also be taken into account as a crucial element of urban development [66].

Furthermore, laws must be made to preserve the best agricultural land. For example, in the State of Oregon, a combination of policies is effective in preserving the best agricultural land in the face of urban expansion. This consists of preserving agricultural land for agriculture in exclusively agricultural areas. Also, the limits of urban growth check urban sprawl, and the exurban districts meet the demand for rural residential development without harming commercial farms. In doing so, the deferral of the farm tax and the right to farm laws encourage farmers to continue farming [22]. The Oregon experience deserves a try in Mali, taking into account local realities. In Mali, it is imperative to reflect further on the status and role of community institutions, institute appropriate observation mechanisms (identification), and formalize collective and individual customary rights. Measures must be taken to ensure the effectiveness of the decrees through regular monitoring of the implementation of the texts, punishment of offenders, and putting the victims of administrative faults in their rights. Land transactions must be better regulated, particularly by ensuring the protection of all right holders, during transactions on both registered and unregistered land. In addition, urban planning must be better organized. Good policy management requires that the land conversion processes be done 
rationally and that the productivity of remaining resources in the agricultural sector be improved. When good plans are developed, they must also be implemented [66]. Moreover, in the case of Ghana, incorporating customary and modern land management could be tried in Mali. In Ghana, customary land secretariats (CLSs) are created to formalize and strengthen the administration and management of customary lands in the context of decentralized land administration. Collaboration with public land sector agencies, especially in areas of sharing information on rights, uses, disputes, and preparation of planning layouts is paramount. These registries are mere extensions of the state land administration apparatus as service units under the deconcentration of land administration powers. The primary reasons for establishing the CLSs, according to the owners and managers of customary lands, are land documentation and dispute resolution. [70]. Also, to succeed in the reform, one can draw inspiration from the land law and the village land law as created in 1999 in Tanzania to designate the existing and well-established village councils as land managers. They will be responsible for overseeing community decisions regarding the designation of village land as household, clan, community, or other land. The village councils will be responsible for the arbitration, as well as the registration processes in the village land register. The titration will be carried out by the commissioner's office and supervised by the village council. Wily, in his analysis of the new legislation, hails the Tanzanian example as one that guarantees democratization [71]. Future directions of research may focus on land governance, impacts on the loss of agricultural land and poverty in peri-urban areas, and the adaptation strategies of farmers in the face of the degradation of their livelihoods following urbanization, etc.

\subsection{Limitations of the Study}

This study had certain limits relating to the lack of available data on the study area we surveyed. Additionally, we could not sample the views of many individuals, partly because of the insecurity in Mali. Notwithstanding the reasons stated above, the responses of the participants were generally similar, indicating that the information they provided was more likely to be the true reflection of the situation among the entire population. Hence, the relatively small sample size of the study does not invalidate our results.

\section{Conclusions and Policy Implications}

\subsection{Conclusions}

Urbanization is both a consequence of development and a driving force for accelerating this development. For example, urbanization promotes education, medical care, and various other social security services. Moreover, urbanization contributes to developing consumer activity sectors, such as commerce, catering, and tourism, and production-oriented sectors such as finance, insurance, and logistics. However, urbanization has significant negative effects on agricultural land in peri-urban areas.

Our study showed that despite the infrastructural set-ups, such as the GDCM factory, the University of Ségou, technical and vocational schools, the urbanization of Ségou had a significant adverse effect on the peri-urban municipality of Sebougou. For example, urbanization has influenced the livelihood of farmers as a result of the large loss of agricultural land in Sebougou, reduction in agricultural output, and a decrease in farmer's income. Increasingly, the end of peri-urban agriculture is taking shape and is marked by the presence of landless farmers. As consequences, poverty and food insecurity remain issues of great concern and young people go abroad or to gold mining sites of Kayes in Mali.

\subsection{Policy Implications}

Based on the findings of the present study, we recommend that the government implement land mapping and an appropriate land registration system necessary for urban planning. This can specifically 
help in the exhaustive demarcation of the different spaces, such as areas reserved for agriculture. In addition, Mali's land law should protect agricultural land by limiting the rate of conversion of this land for urbanization needs or by replacing agricultural land already converted far from urban centers. Also, there should be agrarian land preservation policies that influence the land market by increasing the productive value of agricultural land. Urban sprawl must take place where agricultural spaces have no future; that is, more or less delayed urbanization. Additionally, policies must eliminate the inefficient speculative value of agricultural land. In addition, local populations must benefit more from the positive outcomes of urbanization such as improved infrastructure, services, and job opportunities. The most recent land reform, the 2017 Agricultural Land Law, has various provisions that could help in addressing the issue of land security in Mali, especially for poor smallholder farmers, women, and youth. However, to date, the relevant decrees to activate the implementation have not been passed. Hence, prioritizing the implementation of the reform is a key step to solving the land issues in Mali.

Finally, we recommend that future studies focus on identifying adaptation strategies that could help indigenous farmers in peri-urban areas to cope with the adverse effects of urban expansion such as the loss of agricultural lands.

Author Contributions: Conceptualization, S.L. and B.C.; methodology, B.C. and S.L.; software, B.C.; validation, S.L. and B.C.; formal analysis, B.C.; investigation, B.C.; resources, B.C.; data curation, B.C.; writing-original draft preparation, B.C.; writing-review and editing, S.L.; visualization, B.C.; supervision, S.L.; project administration, S.L.; funding acquisition, S.L. All authors have read and agreed to the published version of the manuscript.

Acknowledgments: The helpful comments of the three anonymous reviewers are gratefully acknowledged. We also thank Gideon Sagoe and Garfield Wayne Hunter for the technical and English language editing, and Li Huang for valuable comments and suggestions.

Conflicts of Interest: The authors declare no conflict of interest.

\section{References}

1. Majale, M. Towards Pro-Poor Regulatory Guidelines for Urban Upgrading: A Review of Papers Presented at the International Workshop on regulatory guidelines for Urban Upgrading; Intermediate Technology Development Group: Bourton-on-Dunsmore, UK, 2002.

2. United Nations Department of Economic and Social Affairs, Population Division. World Urbanization Prospects: The 2018 Revision; United Nations Department of Economic and Social Affairs: New York, NY, USA, 2019.

3. UN-Habitat. World Cities Report 2016: Urbanization and Development-Emerging Future; UN-Habitat: Nairobi, Kenyas, 2016.

4. Satterthwaite, D.; McGranahan, G.; Tacoli, C. Urbanization and its implications for food and farming. Philos. Trans. R. Soc. B 2010, 365, 2809-2820. [CrossRef] [PubMed]

5. Sargeson, S. Violence as development: Land expropriation and China's urbanization. J. Peasant Stud. 2013, 40, 1063-1085. [CrossRef]

6. Mesple-Somps, S.; Selod, H.; Spielvogel, G.; Blankespoor, B. Urbanisation et croissance dans les villes du Mali. In Le Mali Contemporain; Brunet-Jailly, J., Charmes, J., Konaté, D., Institut de Recherche pour le Développement, Eds.; IRD Éditions: Montpellier, France, 2014; pp. 545-580.

7. Fay, M.; Opal, C. Urbanization without Growth: A not so Uncommon Phenomenon; World Bank: Washington, DC, USA, 2000.

8. Dauvergne, S. Dynamique des Agricultures Périurbaines en Afrique Sub-Saharienne et Statuts Fonciers: Le Cas Des Villes d'Accra et Yaoundé; hal-00539873f; HAL: Bengaluru, India, 2010.

9. Adam, A.G. Informal settlement in peri-urban areas of Bahir Dar, Ethiopia: An institutional analysis. Habitat Int. 2014, 43, 90-97. [CrossRef]

10. Lasisi, M.; Popoola, A.; Adediji, A.; Adedeji, O.; Babalola, K. City expansion and agricultural land loss within the peri-urban area of Osun State, Nigeria. Ghana J. Geogr. 2017, 9, 132-163.

11. Ngana, F.; Sougnabé, P.; Gonné, B.; Ababa, A.M. Transformations foncières dans les espaces périurbains en Afrique centrale soudanienne. In Proceedings of the Savanes Africaines en Développement: Innover Pour Durer, Garoua, Cameroun, 20-23 April 2009; pp. 1-9. 
12. Pham, V.C.; Pham, T.T.H.; Tong, T.H.A.; Nguyen, T.T.H.; Pham, N.H. The conversion of agricultural land in the peri-urban areas of Hanoi (Vietnam): Patterns in space and time. J. Land Use Sci. 2014, 10, $224-242$. [CrossRef]

13. Firdaus, G.; Ahmad, A. Impact analysis of urbanization on rural livelihood-an empirical study of an urban centre of Delhi, India. Int. J. Urban Sci. 2011, 15, 147-160. [CrossRef]

14. Pandey, B.; Seto, K.C. Urbanization and agricultural land loss in India: Comparing satellite estimates with census data. J. Environ. Manag. 2015, 148, 53-66. [CrossRef] [PubMed]

15. Su, S.; Jiang, Z.; Zhang, Q.; Zhang, Y. Transformation of agricultural landscapes under rapid urbanization: A threat to sustainability in Hang-Jia-Hu region, China. Appl. Geogr. 2011, 31, 439-449. [CrossRef]

16. Peng, K.; Bai, X. Welfare effects of rural-urban land conversion on different aged land-lost farmers: Exemplified in Wuhan city. Chin. J. Popul. Resour. Environ. 2016, 14, 45-52. [CrossRef]

17. Wang, H.; Zhu, P.; Chen, X.; Swider, S. Land expropriation in urbanizing China: An examination of negotiations and compensation. Urban Geogr. 2016, 38, 401-419. [CrossRef]

18. Francis, C.A.; Hansen, T.E.; Allison, A.F.; Hesje, P.J.; Nelson, H.E.; Lawseth, A.E.; English, A. Farmland conversion to non-agricultural uses in the US and Canada: Current impacts and concerns for the future. Int. J. Agric. Sustain. 2012, 10, 8-24. [CrossRef]

19. Martellozzo, F.; Ramankutty, N.; Hall, R.J.; Price, D.T.; Purdy, B.; Friedl, M.A. Urbanization and the loss of prime farmland: A case study in the Calgary- Edmonton corridor of Alberta. Reg. Environ. Chang. 2014, 15, 881-893. [CrossRef]

20. Li, S. Change detection: How has urban expansion in Buenos Aires metropolitan region affected croplands. Int. J. Digit. Earth 2017, 11, 195-211. [CrossRef]

21. Wadduwage, S. Peri-urban agricultural land vulnerability due to urban sprawl-a multi-criteria spatially-explicit scenario analysis. J. Land Use Sci. 2018, 13, 358-374. [CrossRef]

22. Nelson, A.C. Preserving prime farmland in the face of urbanization: Lessons from Oregon. J. Am. Plan. Assoc. 1992, 58, 467-488. [CrossRef]

23. Clément, C.; Abrantes, P. Préserver les espaces agricoles périurbains face à l'étalement urbain. Une problématique locale? Innov. Agric. Urbaines Durables 2011, 211, 67-82. [CrossRef]

24. Dumitrache, L.; Zamfir, D.; Nae, M.; Simion, G.; Stoica, I.V. The urban nexus: Contradictions and dilemmas of (Post) Communist (sub) urbanization in Romania. J. Stud. Res. Hum. Geogr. 2016, 10, 40-58. [CrossRef]

25. Izakovičová, Z.; Mederly, P.; Petrovič, F. Long-term land use changes driven by urbanisation and their environmental effects (example of Trnava city, Slovakia). Sustainability 2017, 9, 1553. [CrossRef]

26. Neimark, B.; Toulmin, C.; Batterbury, S. Peri-urban land grabbing? Dilemmas of formalising tenure and land acquisitions around the cities of Bamako and Ségou, Mali. J. Land Use Sci. 2018, 13, 319-324. [CrossRef]

27. Benjaminsen, T.A.; Sjaastad, E. Race for the prize: Land transactions and rent appropriation in the Malian cotton zone. Eur. J. Dev. Res. 2002, 14, 129-152. [CrossRef]

28. Camara, F. Les titres fonciers autour de Bamako: Modes d'accès et impacts sur les usages. VertigO $2017,17$. [CrossRef]

29. Bourdarias, F. La ville mange la terre. Désordres fonciers aux confins de Bamako. J. Des Anthropol. 1999, 77-78, 141-160. [CrossRef]

30. Platteau, J.P. The evolutionary theory of land rights as applied to Sub-Saharan Africa: A critical assessment. Dev. Chang. 1996, 27, 27-86. [CrossRef]

31. Runezerwa, A.N. Impact de Politique Étatique en Matière Foncière Sur le Développement Rural au Rwanda. Available online: https://www.memoireonline.com/a/fr/cart/add/4032 (accessed on 22 June 2019).

32. Feder, G.T.; Onchan, T.; Chalamwong, T.; Hongladarom, H. Land Policies and Farm Productivity in Thailand; Johns Hopkins University Press: Baltimore, MD, USA, 1988.

33. Searching for Land Tenure Security in Africa; Bruce, J.W.; Migot-Adholla, S.E. (Eds.) The World Bank Group: Washington, DC, USA, 1994.

34. USAID. Land Tenure and Property Rights Regional Report; United States Agency for International Development: Washington, DC, USA, 2007.

35. Markets, Hierarchies and Networks: The Coordination of Social Life, 1st ed; Thompson, G.; Frances, J.; Levačić, R.; Mitchell, J. (Eds.) Sage Publications Ltd.: London, UK, 1991. 
36. Halleux, J.M.; Marcinczak, S.; Van der Krabben, E. The adaptive efficiency of land use planning measured by the control of urban sprawl. The cases of the Netherlands, Belgium and Poland. Land Use Policy 2012, 29, 887-898. [CrossRef]

37. Sýkora, L.; Bouzarovski, S. Multiple transformations: Conceptualising the post-communist urban transition. Urban Stud. 2011, 49, 43-60. [CrossRef]

38. CPS/SDR. Annuaire Statistique 2015 Secteur Développement Rural; Ministère de l'Agriculture: Bamako, Mali, 2015.

39. Herfkens, E.L. Accelerating action towards education for all: Reducing poverty through basic education. Prospects 2001, 32, 255-264.

40. Omideyi, A.K. Family size and productivity of rural households in Nigeria. Janasamkhya 1988, 6, $29-49$. [PubMed]

41. Arthur, J.L. Family Size and Its Socio-Economic Implications in the Sunyani Municipality of the Brong Ahafo Region of Ghana, West Africa; University of Cape Coast: Cape Coast, Ghana, 2005.

42. Noszczyk, T. A review of approaches to land use changes modeling. Hum. Ecol. Risk Assess. 2019, 25, 1377-1405. [CrossRef]

43. Dang, A.N.; Kawasaki, A. A review of methodological integration in land-use Change models. Int. J. Agric. Environ. Inf. Syst. 2016, 7, 1-25. [CrossRef]

44. Field, A. Discovering Statistics Using IBM SPSS Statistics, 4th ed.; Carmichael, M., Ed.; Sage Publications Ltd.: Los Angeles, CA, USA, 2013.

45. INSTAT. Consommation, Pauvreté, Bien-être des Ménages: Rapport D'analyse; Ministère de l'Economie et des Finances: Bamako, Mali, 2017.

46. Sen, A. Poor, relatively speaking. Oxf. Econ. Pap. 1983, 35, 153-169. [CrossRef]

47. Belay, E. Impact of urban expansion on the agricultural land use a remote sensing and GIS approach: A case of Gondar city, Ethiopia. Int. J. Innov. Res. Dev. 2014, 3, 129-133.

48. Becker, L. Migrations et transferts fonciers ruraux: Étude villageoise dans la zone péri-urbaine de Bamako. e-Migrinter 2012, 8, 104-108. [CrossRef]

49. Lodder, E. Pressure on Land in Peri-Urban Vietnam: The Impact of Agricultural Land Conversion and the Need for Livelihood Diversification in Thuy Duong Commune. Master's Thesis, International Development Studies, Faculty of Geosciences, Utrecht University, Utrecht, The Netherlands, 2012.

50. Adam, A.G. Land tenure in the changing peri-urban areas of Ethiopia: The case of Bahir Dar city. Int. J. Urban Reg. Res. 2014, 38, 1970-1984. [CrossRef]

51. Appiah, D.O.; Asante, F.; Nketiah, B. Perspectives on agricultural land use conversion and food security in rural Ghana. Available online: https://www.preprints.org/manuscript/202011.0077/v1 (accessed on 22 June 2019). [CrossRef]

52. Lu, X.; Huang, S. Barriers and solutions to China's cultivated land protection. Int. J. Environ. Stud. 2010, 62, 223-232. [CrossRef]

53. Thontteh, E.O.; Babarinde, J.A. Analysis of land speculation in the urban fringe of Lagos, Nigeria. Pac. Rim Prop. Res. J. 2018, 24, 161-184. [CrossRef]

54. Skidmore, M.; Staatz, J.; Dembélé, N.; Ouédraogo, A. Population growth, land allocation and conflict in Mali. Area Dev. Policy 2016, 113-131. [CrossRef]

55. Grădinaru, S.R.; Iojă, C.I.; Onose, D.A.; Gavrilidis, A.A.; Pătru-Stupariu, I.; Kienast, F.; Hersperger, A.M. Land abandonment as a precursor of built-up development at the sprawling periphery of former socialist cities. Ecol. Indic. 2015, 57, 305-313. [CrossRef]

56. Szturc, J.; Karásek, P.; Podhrázská, J. Historical changes in the land use connected with appropriation of agricultural land. Case study of cadastral areas Dolní Věstonice and Modřice (Czech Republic). Eur. Countrys. 2017, 9, 658-678. [CrossRef]

57. Feranec, J.; Šúri, M.; Ot’ahel', J.; Cebecauer, T.; Kolář, J.; Soukup, T.; Zdeňková, D.; Waszmuth, J.; Vâjdea, V.; Vîjdea, A.; et al. Inventory of major landscape changes in the Czech Republic, Hungary, Romania and Slovak Republic 1970s-1990s. Int. J. Appl. Earth Obs. Geoinf. 2000, 2, 129-139. [CrossRef]

58. FAO. The Future of Food and Agriculture: Trends and challenges; FAO: Rome, Italy, 2017.

59. Benjaminsen, T.A.; Holden, S.; Lund, C.; Sjaastad, E. Formalisation of land rights: Some empirical evidence from Mali, Niger and South Africa. Land Use Policy 2008, 26, 28-35. [CrossRef]

60. Kuusaana, E.D.; Eledi, J.A. As the city grows, where do the farmers go? Understanding Peri-urbanization and food systems in Ghana-Evidence from the Tamale Metropolis. Urban Forum 2015, 26, 443-465. [CrossRef] 
61. Djiré, M.; Kéita, A. Cadre D'analyse de la Gouvernance Foncière, Mali, Rapport Final; Initiative Prospective Agricole et Rurale et FAO: Bamako, Mali, 2016.

62. Galiani, S.; Schargrodsky, E. Property rights for the poor: Effects of land titling. J. Public Econ. 2010, 94, 700-729. [CrossRef]

63. Bertrand, M. "A cadastre for Mali?" The production of land titles and the challenge of property data on the periphery of Bamako. Land Use Policy 2019, 81, 371-381. [CrossRef]

64. Kalabamu, F.T. Land tenure reforms and persistence of land conflicts in Sub-Saharan Africa -The case of Botswana. Land Use Policy 2019, 81, 337-345. [CrossRef]

65. Farah, N.; Khan, I.A.; Manzoor, A. Changing land ownership patterns and agricultural activities in the context of urban expansion in Faisalabad, Pakistan. Pak. J. Life Soc. Sci. 2016, 14, 183-188.

66. Deng, X.; Huang, J.; Rozelle, S.; Uchida, E. Cultivated land conversion and potential agricultural productivity in China. Land Use Policy 2006, 23, 272-384. [CrossRef]

67. HiiL. Besoins et Satisfaction en Matière de Justic au Mali: Problèmes Juridiques Dans la vie Quotidienne; Hague Institute for Innovation of Law: Hague, The Netherlands, 2018.

68. Marta, A.D.; Suwaryo, U.; Sulaeman, A.; Agustino, L. Dilemma of customary land policy in Indonesia. Masyarakat, Kebud. dan Polit. 2019, 32, 134-143. [CrossRef]

69. Mondiale, B. Des Politiques Foncières Pour Promouvoir la Croissance et Réduire la Pauvreté: Résumé Analytique; Banque Mondiale: Washington, DC, USA, 2003.

70. Biitir, S.B.; Nara, B.B.; Ameyaw, S. Integrating decentralised land administration systems with traditional land governance institutions in Ghana: Policy and praxis. Land Use Policy 2017, 68, 402-414. [CrossRef]

71. Manji, A. Land reform in the shadow of the state: The implementation of new land laws in Sub-Saharan Africa. Third World Q. 2001, 22, 327-342. [CrossRef]

Publisher's Note: MDPI stays neutral with regard to jurisdictional claims in published maps and institutional affiliations. 